\title{
Dietary Approaches to Attain Fish Health with Special Reference to their Immune System
}

\author{
Thea Magrone $^{1, *}$, Matteo Antonio Russo ${ }^{2}$ and Emilio Jirillo ${ }^{1}$ \\ ${ }^{1}$ Department of Basic Medical Sciences, Neuroscience and Sensory Organs, University of Bari, School of Medicine, Bari, Italy; \\ ${ }^{2}$ MEBIC Consortium, San Raffaele Open University of Rome and IRCCS San Raffaele Pisana of Rome, Rome, Italy
}

\begin{abstract}
Fish despite their low collocation in the vertebrate phylum possess a complete immune system. In teleost fish both innate and adaptive immune responses have been described with melanomacrophage centers (MMCs) equivalent to mammalian germinal centers. Primary lymphoid organs are represented by the thymus and kidney, while spleen and mucosa-associated lymphoid tissues act as secondary lymphoid organs. Functions of either innate immune cells (e.g., macrophages and dendritic cells) or adaptive immune cells ( $\mathrm{T}$ and B lymphocytes) will be described in detail, even including their products, such as cytokines and antibodies. In spite of a robust immune arsenal, fish are very much exposed to infectious agents (marine bacteria, parasites, fungi, and viruses) and, consequentially, mortality is very much enhanced especially in farmed fish. In fact, in aquaculture stressful events (overcrowding), microbial infections very frequently lead to a high rate of mortality. With the aim to reduce mortality of farmed fish through the reinforcement of their immune status the current trend is to administer natural products together with the conventional feed. Then, in the second part of the present review emphasis will be placed on a series of products, such as prebiotics, probiotics and synbiotics, $\beta$-glucans, vitamins, fatty acids and polyphenols all used to feed farmed fish. With special reference to polyphenols, results of our group using red grape extracts to feed farmed European sea bass will be illustrated. In particular, determination of cytokine production at intestinal and splenic levels, areas of MMCs and development of hepatopancreas will represent the main biomarkers considered. All together, our own data and those of current literature suggests that natural product administration to farmed fish for their beneficial effects may, in part, solve the problem of fish mortality in aquaculture, enhancing their immune responses.
\end{abstract}

Keywords: Aquaculture, cellular and molecular rehabilitation, fish, immunity, lymphocytes, melanomacrophage centers, natural products.

\section{INTRODUCTION}

Despite their low position in the vertebrate phylum, fish possess quite robust immune machinery, which allows them to survive in a very hostile environment. In analogy to mammals, fish immunity can be divided into two major compartments, namely the innate and the adaptive immune system. In fact, teleost fish possess both primary and secondary lymphoid tissues and, specifically, thymus and head-kidney represent primary organs while the spleen and the mucosa-associated lymphoid tissues (MALTs) are secondary organs. In turn, MALTs can be divided into gut-associated lymphoid tissue, gill-associated lymphoid tissue (GIALT), skin-associated lymphoid tissue and nasopharinx-associated lymphoid tissue [1]. MALTs are covered by a protective layer of mucus containing antibodies which interact with both commensal and invading microorganisms [2-4]. They are not organized lymphoid structures as in the case of mammal lymph nodes but fish myeloid and lymphoid cells constitute a diffuse network, even if an interbranchial lymphoid tissue has been identified in GIALT [5]. As later discussed in this review, melanomacrophage centers (MMCs) are pigmented phagocytes distributed in kidney, spleen and liver of fish [6-8]. MMCs belong to the innate immunity and are considered as precursors of the mammal germinal centers (GCs) [9]. Furthermore, in fish, innate immunity is based on the function of other immune cells, such as granulocytes, macrophages and dendritic cells (DCs), but also non-immune cells, such as intestinal M-like cells, red blood cells and thrombocytes participate to immune defense [10-17].

*Address corrospondance to this author at the Department of Basic Medical Sciences, Neuroscience and Sensory Organs, School of Medicine, University of Bari, School of Medicine, P.zza Giulio Cesare 11, 70124 Bari, Bari, Italy; Tal: +39 0805478492; E-mail: thea.magrone@uniba.it
Fish innate-like lymphocytes are positioned between innate and adaptive immunity, and, in particular, extrathymic $\gamma \delta \mathrm{T}$ cells have been identified [18-20]. As discussed in the next section of this review, fish intestine represents the major source of innate-like lymphocytes in analogy to mammalian-like lymphocytes [21].

With special reference to fish adaptive immunity, both $\mathrm{CD}^{+}$ and $\mathrm{CD} 8^{+}$cells are largely present in MALTs and their phenotypes and functions will be discussed in a specific section of this review [22-24]. B cells are also contained in MALTs and immunoglobulin (Ig)T represents the equivalent of secretory IgA in mammals, thus, protecting mucosal sites from invading pathogens [25]. Despite a robust immune system, fish succumb because of severe infections and, especially, in farmed fish mortality is very high due to invasion by pathogens and stressful environmental conditions [26, 27]. Therefore, preserving fish health in aquaculture and prevention of disease is a major focus of the current research in this field. This achievement may result from the combination of different strategies such as innovative feeds, low fish density and corroboration of the immune response [28]. Particularly, administration to fish of dietary supplements has been increasing in the last few years and, here, this procedure will be elucidated in detail.

On these grounds, aims of the present review are the illustration of piscine innate and adaptive immune responses but also of the role played by natural products in the enhancement of fish immunity against infectious challenges and stressful conditions.

\section{INNATE IMMUNITY}

\subsection{Melanomacrophage Centers (MMCs)}

MMCs are nodular accumulations of melanin-macrophages mostly distributed in kidney, spleen and liver of fish. Pigments 
(lipofuscin, melanin and hemosiderin) contained in MMCs can be of both exogenous and endogenous origin and the latter is derived from phagocytosed erythrocytes [29]. This last event suggests that MMCs play a role in iron recycling similarly to hemosiderin-laden splenic macrophages in mammals [30]. Besides erythrocytes, there is evidence that MMCs phagocytose pathogens [31, 32]. In turbot, the evidence that splenic MMCs are in close association with ellipsoids (which are capillaries) may suggest their property to phagocytose blood-borne pathogens [33]. Besides the above mentioned functions, MMCs have been considered as primitive precursors of mammalian GCs, even if such a contention needs further validation. In fact, fish lack GCs and MMCs, which may also be due to the adaptive immune responses $[34,35]$. In this framework, fish immunized with bacteria are able to retain antigens in and around splenic MMCs, trapped within immune complexes (ICs) and such retention can be enhanced by injection of preformed ICs [36-38]. More specifically, the above results support a similarity between MMCs and mammalian follicular DCs in the context of GCs, thus, allowing antigen presentation to T helper (h) 2 cells, and ultimately, promoting B-cell antibody formation [39].

Conclusively, as recently reviewed by Steinel and Bolnick [40], one can hypothesize that MMCs have evolved as "garbage dumps" from a common precursor of vertebrates, and, then, after meeting pathogens and antigens have acquired immunological functions, finally, evolving into GCs.

\subsection{Macrophages}

Fish macrophages are distributed in mucosal and non-mucosal tissues (spleen, kidney and liver) and in analogy to the mammal counterpart can also be divided into subsets. In mammals, one can distinguish M1 (classically activated macrophages) and M2 a, b and c (alternatively activated macrophages) [41]. Functionally, M1 are inflammatory, while M2 and, mostly, M2c are anti-inflammatory cells, also secreting angiogenic mediators for the resolution of inflammation. In particular, M1 cells exert phagocytosis of pathogens, produce free radicals and pro-inflammatory mediators [4244]. M2 fish macrophages have been analyzed for arginase gene expression and activity, as well as, gene expression and function of interleukin (IL)-10 and transforming growth factor- $\beta$. However, the fine regulatory mechanisms involved in the polarization toward M2a-c cells need further investigation [45-47].

Colony stimulating factor (CSF)-1 represents the major growth factor for fish macrophages and in most fish CSF-1.1 and CSF-1.2 molecules have been identified [48]. CSF-1.1 promotes the differentiation toward M1 macrophages in goldfish (Carassius auratus) [49]. In support of the above finding, evidence has been provided that a soluble CSF-1 receptor inhibits the pro-inflammatory pathway in goldfish macrophages. Quite interestingly, in some fish species, two distinct csflr genes have been detected, thus, suggesting that these animals have elaborated more complex mechanisms of macrophage differentiation in comparison to mammals [50].

In order to cope with pathogens, fish macrophages bear both extracellular and intracellular pattern recognition receptors (PRRs). At least five types of PRRs have been identified, namely, Toll-like receptors (TLRs), c-type lectins, nucleotide-binding domainleucine-rich repeat containing receptors (NLRs or NOD-like), retinoic acid inducible gene I-like receptors and absence in melanomalike receptors [51]. Besides macrophages, also neutrophils, monocytes, DCs, epithelial and endothelial cells possess PRRs. Bony fish display 17 TLRs with TLRs 20-23 present only on fish [52, 53]. Of note, not all fish bear TLR-4, a specific receptor for Gram-negative lipopolysaccharides (LPS) and, in particular, zebrafish TLR-4 does not recognize LPS [54]. NLRs have been identified in fish and seem to share conserved structural domains with mammalian NLRs. In this respect, studies have been focused on gene expression and to a lesser extent on signaling following NLR stimulation $[55,56]$.
Fish M1 macrophages exert a potent anti-microbial activity which encompasses different phases. Following phagocytosis of pathogens, generation of superoxide anions (respiratory burst) and nitric oxide (NO) production are two independent macrophagemediated anti-microbial functions [57]. Another mechanism related to the microbicidal activity of M1 macrophages is the indoleamine 2,3-dioxygenase (IDO)-mediated degradation of tryptophan [58]. However, IDO can control immune response via production of kinurenins and, in turn, interferon (IFN)- $\gamma$-stimulated macrophages produce IDO $[59,60]$. Fish M2 macrophages play both antiinflammatory and pro-healing effects. The fish IL-4/13a and IL$4 / 13$ b exert anti-inflammatory effects, dampening the gene expression of pro-inflammatory cytokines, such as tumor necrosis factor (TNF)- $\alpha$, IL-1 $\beta$ and IFN- $\gamma[61,62]$. Quite interestingly, fish M2c macrophages under influence of cortisol up-regulate the IL-10 gene expression and in the gold fish recombinant IL-10 suppresses reactive oxygen species production and inflammatory gene expression [63]. Arginase production is a marker of M2 cell activity in fish [64]. In fact, arginase converts L-arginine to L-ornithine which, in turn, represents a precursor for polyamine and proline constituents of collagen for tissue repair to occur [65]. Fish possess both arginase- 1 and arginase-2 genes with M1 cells expressing more inducible nitric oxide synthase gene (inflammatory profile) and M2 cells expressing more arginase genes (anti-inflammatory/tissue repairing profile) [66].

Fish macrophages also serve as antigen presenting cells (APCs) and interact with $\mathrm{T}$ lymphocytes via the major histocompatibility complex (MHC)-1 expression, whose extent is different according to species [67]. Of note, some fish species have lost the MHC-II, even if they mount an effective immune response against pathogens $[68,69]$. Other fish species have expressed non-classical MHCs whose lineages have separated before the emergence of tetrapods [70]. In this framework, it is important to emphasize the role of fish DCs which act as APCs. DCs express MHC-II and CD83 markers, also exerting potent phagocytic properties and induction of $\mathrm{CD}^{+} \mathrm{T}$ cell production [70-72].

In this context, the immune role exerted by fish erythrocytes is worth mentioning. In vitro studies have demonstrated that trout erythrocytes are able to engulf Candida $(C$.) albicans particles and present them to surrounding head-kidney macrophages [13, 14]. Furthermore, mature fish erythrocytes which have engulfed $C$. albicans have been shown to release in supernatants cytokine-like factors able to potentiate macrophage function, while inhibiting their migration (macrophage inhibition factor-like activity) [15]. Furthermore, evidence has been provided that $C$. albicans phagocyting trout erythrocytes form aggregates with macrophages (the so-called rosettes), thus traveling via circulation to distant organs, and, finally, contributing to the formation of MMCs [16]. Quite interestingly, in infected trout with $C$. albicans, evidence of rosette formation in blood has been provided, and, in addition, fish thrombocytes were present in close association with erythrocytes [17]. These data suggest that fish thrombocytes may also play an immunological role in the clearance of $C$. albicans. Major innate immune cells functions are summarized in Table 1.

\section{FISH LYMPHOCYTES}

In a recent review [73], the question has been poised on the equivalence between fish lymphocytes and mammalian innate-like $\mathrm{T}$ cells. In mammals and fish, innate-like $\mathrm{T}$ cells are mostly located in the intestine as intestinal intraepithelial lymphocytes (IELs) characterized by an archaic T cell receptor (TCR), the so called $\gamma \delta \mathrm{TCR}[74,75] . \gamma^{+} \delta^{+}$cells can develop extrathymically in the absence of antigen encountering and exert an array of functions, such as direct killing of infected cells, tumor immunosurveillance, cytotoxicity and release of both regulatory and pro-inflammatory cytokines [76]. Quite interestingly, subsets of murine $\gamma \delta$ cells have been identified which are activated by innate stimuli rather than TCR 
Table 1. Main innate immune cells in fish.

\begin{tabular}{|c|c|}
\hline Cell types & Functions \\
\hline \hline $\begin{array}{c}\text { Macrophages } \\
\text { Melanomacrophage centers }\end{array}$ & $\begin{array}{c}\text { Accumulation of pigmented macrophages with phagocytic activity [35] and primitive precursors of mammalian } \\
\text { germinal centers [34, 35]. }\end{array}$ \\
\hline M1 and M2 $(\mathrm{a}, \mathrm{b}, \mathrm{c})$ macrophages & M1 are phagocytic macrophages that produce free radicals and pro-inflammatory cytokines [42-44]. \\
& $\begin{array}{r}\text { M2 macrophages prevalently exert anti-inflammatory activities [45-47]. } \\
\text { In general terms, macrophages act as antigen presenting cells to T lymphocytes via MHC-I. }\end{array}$ \\
\hline
\end{tabular}

ligation and known as IL-17 producing $(\gamma \delta \mathrm{T}-17)$ and IFN- $\gamma$ producing $(\gamma \delta$ T-IFN- $\gamma)$ cells [77].

Innate-like $\mathrm{B}$ cells in the mammals are the B1-B cells also subdivided into $\mathrm{B} 1 \mathrm{a}$ and $\mathrm{B} 1 \mathrm{~b}-\mathrm{B}$ cells [78]. B1 cells secrete natural polyreactive antibodies in a $\mathrm{T}$-independent fashion, being phagocytic, microbicidal and involved in autoimmune processes [79, 80].

In teleost fish, $\mathrm{T}$ cells are largely present in gills and intestine and express the TCR $\alpha \beta$ on their surface in the presence of either CD4 coreceptor or CD8 coreceptor. Then, $\mathrm{CD}^{+}{ }^{\mathrm{T}} \mathrm{Th}$ cells, $\mathrm{CD} 8^{+} \mathrm{T}$ cytotoxic cells, $\mathrm{T}$ regulatory (Treg) cells and Th17 cells have been identified [81-83].

Fish intestine is the major site of immune responses as described below. In the intestine, IEL in vivo undergo recombinantactivating gene (RAG)-mediated somatic rearrangement of a given $\mathrm{V} / \mathrm{C}$ combination in the CDR3 junction length of TCR $\beta$ chain/TCR $\gamma$-chain $[84,85]$. Conversely, gill $\mathrm{T}$ cells in vitro proliferate when stimulated by lectins but do not express RAG [86]. In the sea bass intestine, evidence has been provided that $\mathrm{T}$ cells express RAG-1, TCR $\alpha, \mathrm{TCR} \gamma, \mathrm{CD} 8 \alpha$ and $\mathrm{CD} 4$, thus, suggesting that gut is the main source of T cells in adult fish [87]. Conversely, gills can be considered as a source of $\mathrm{T}$ cells committed as effector/helper cells [86]. In this context, a special issue is undoubtedly represented by fish immune tolerance. Sugimoto and associates [88] have clearly demonstrated that zebrafish lacking a functional FoxP3 ortholog exhibit a reduced survival with the development of a proinflammatory profile. In fact, in analogy to mammals, Treg cells are controlled by a master regulatory gene encoding FoxP3. The same group has also demonstrated that zebrafish Treg cells mediate organ-specific regeneration, while in the absence of FoxP3 deficient Treg cells infiltrate damaged organs (e.g., spinal cord, heart and retina) but do not express regenerative factors [89]. Furthermore, the intrabranchial lymphoid tissue in gills promotes immune tolerance in view of its high expression of FoxP3 [90]. This homeostatic mechanism seems to be very effective in the gills where continuous exposure to a variety of antigens may lead to exaggerated inflammatory immune responses. Main functions of $\mathrm{T}$ lymphocytes are expressed in Table 2.

Table 2. Subsets of fish T lymphocytes.

\begin{tabular}{|c|c|}
\hline Cell types & Functions \\
\hline$\gamma^{+} \delta^{+} \mathrm{T}$ cells & $\begin{array}{l}\text { Direct killing of infected cells, immunosurveil- } \\
\text { lance, cytotoxicity and release of both regulatory } \\
\text { and pro-inflammatory cytokines [76]. }\end{array}$ \\
\hline $\begin{array}{c}\alpha^{+} \beta^{+} \mathrm{T} \text { cells } \\
\left(\mathrm{CD} 4^{+} \text {Th cells, }\right. \\
\mathrm{CD} 8^{+} \mathrm{T} \text { cytotoxic } \\
\text { cells, Treg cells } \\
\text { and Th } 17 \text { cells })\end{array}$ & $\begin{array}{l}\text { Gill and intestinal T cells are the major sites of } \\
\text { these lymphocytes and their anti-inflammatory } \\
\text { activity is prevalent }[89,90] \text {. }\end{array}$ \\
\hline
\end{tabular}

The origin of fish $B$ cells is still uncertain. In zebrafish, the pancreas has been indicated as the primary source of B cells [91]. In sea bass, the presence of IgM producing cells in kidney may suggest that this organ is the primary site of B cell production [92]. Fish B cells express $\mu, \theta, \delta$ genes which lead to three different Ig classes, namely, $\operatorname{IgM}$, IgT and $\operatorname{IgD}$, as recently reviewed by Flajink [93]. IgM are tetrameric and their concentration is very abundant in biological fluids [94]. IgT (for immunoglobulin teleost) is a mucosal antibody isotype produced as a monomer [95]. However, in trout mucus a non-covalent polymeric IgM association has been reported [96]. Finally, IgD is expressed in monomeric form and in analogy to humans it can be involved in inflammatory responses binding to a still unknown receptor on the surface of basophils [97]. In Table 3, fish antibody classes and functions are outlined.

Table 3. Antibody classes in fish.

\begin{tabular}{|c|c|}
\hline Class & Functions \\
\hline $\operatorname{IgM}$ & $\begin{array}{l}\text { They are tetrameric and very abundant in biologic fluids of } \\
\text { non-immunized fish [93]. }\end{array}$ \\
\hline $\operatorname{IgT}$ & $\begin{array}{l}\text { This is a mucosal antibody equivalent to mammalian IgA and } \\
\text { produced as a monomer [95]. }\end{array}$ \\
\hline $\operatorname{IgD}$ & $\begin{array}{l}\text { They are monomeric, being involved in inflammatory activi- } \\
\text { ties via binding to basophils }[97,98] .\end{array}$ \\
\hline
\end{tabular}

Conclusively, according to Scapigliati and associates [73] fish B cells have certain properties, such as elevated concentration of $\operatorname{IgM}$ in non-immunized fish, low increase of $\operatorname{IgM}$ affinity following secondary immunization, possible expression of TLRs and pathogen phagocytosis, kidney B1-B cells similar to the splenic murine counterpart and proliferating B cells in peritoneum. Quite interestingly, the first teleost CD5 molecule has recently been identified [98]. This finding represents an additional evidence of phenotypical and functional similarities between fish $\operatorname{IgM}^{+} \mathrm{B}$ cells and mammalian $\mathrm{B} 1$ cells.

There are experimental evidences in favor of immunological memory in fish which are mostly based on adoptive transfer of peripheral leukocytes from vaccinated donors to naïve histocompatible recipients [99]. Cell transfer experiments afford long term protection in recipients but if the mechanisms triggered by these cells may be considered "memory" needs further clarification.

As indicated in the previous paragraphs, fish lymphocytes are able to secrete an array of cytokines. In this regard, the best studied fish T lymphocyte cytokine is IFN- $\gamma$ as a product of Th1 cells [100]. Two different types of IFN- $\gamma$ have been identified in fish, namely IFN- $\gamma$ and IFN- $\gamma$ rel [101]. A functional dichotomy has been observed in these two types of fish IFN- $\gamma$, mostly, in terms of their effects on macrophages and monocytes, as extensively reported by Grayfer and associates [102, 103]. It would be very interesting to decipher whether there are differences between these two 
IFNs in exerting antimicrobial activities against various fish pathogens.

At the end of this section, one has to emphasize that teleost fish possess a commensal microbiota able to shape the immune response, as recently reviewed [104]. Studies on the interaction between fish microbiota and immune system will contribute to solve problems in aquaculture system, preventing development of infections.

\section{NATURAL PRODUCTS AS MODULATORS OF FISH IMMUNE RESPONSE}

Fish disease (viral, bacterial, fungal and parasitic infections) have been increasing, thus, causing noticeable economical losses in the aquaculture industry [105-107]. Particularly, juvenile marine fish undergo elevated mortality rate during the larvae culture phase due to chronic stress and bacterial infections [108, 109]. In aquacultures, high population density and manipulation seem to favor growth of opportunistic bacteria with reduction of beneficial microorganisms, thus, leading to mortality $[110,111]$. In order to overcome the problem of fish mortality three main strategies have been adopted, namely: i. the maintenance of microbiota equilibrium in aquaculture; ii. the improvement of water quality and, finally, iii. the enhancement of the immune response by larvae [112]. With regard to immune enhancement in teleost fish, immune stimulation strategy is based on the application of compounds which potentiate the function of phagocytic cells, thus, increasing their bactericidal and fungicidal functions [113]. The observed high mortality in larvae may depend on their immature adaptive immune system, and, therefore, immune stimulation may be very effective on their natural arm of immunity [114]. In synthesis, larval stage is a very critical phase in aquaculture where application of immunostimulant strategies appears to be more effective. On these grounds, in the next paragraphs several compounds of natural origin will be illustrated for their capacity to regulate/potentiate fish immune response in aquaculture.

\subsection{Prebiotics, Probiotics, Synbiotics}

According to Bindels and associates [115], "prebiotic concept typically refers to non digestible food ingredients or substances that pass undigested through the upper part of the gastrointestinal tract and stimulate the growth and/or activity of health-promoting bacteria that colonize the large bowel." Major prebiotics are fructose oligosaccharides (FOS), galactose oligosaccharides (GOS), xylose oligosaccharides (XOS), inulin, polydextrose, dietary fibers and mannan-oligosaccharides [116]. Prebiotics administered to fish as food or feed ingredients beneficially impact on the fish intestinal immune system [117]. Common carp fed FOS, GOS and inulin underwent a significant increase in skin mucus lysozyme activity, especially in GOS-fed group [118]. Administration of GOS to Caspian white fish increased immunoglobulin levels [119]. In zebrafish, administration of sodium propionate increased appetite and mucus gene expression [120]. In a series of reports, evidence has been provided that administration of prebiotics to fish has led to increased anti-inflammatory cytokine expression and regulation of appetite gene expression also via production of short chain fatty acids (SCFAs) [121-126]. Other lines of evidence have documented that prebiotics are able to increase intestinal digestion and absorption in juvenile golden pompano, augmenting villus length, villus width and their numbers as well muscle thickness at all gut segments [127]. In zebrafish, administration of chitosan silver nanocomposites reduced the number of Proteobacteria (a phylum of Gram-negative bacteria enriched in pathogens) [128]. Conclusively, as recently reviewed [129], prebiotics in addition to a direct effect on the fish gut immune system are digested by intestinal microbiota for the production of SCFAs which, in turn, promote the killing of pathogens.
Probiotics are defined as "microorganisms that when consumed (as in food or a dietary supplement) maintain or restore beneficial bacteria to digestive tract" [130]. There are a few evidences on the beneficial effects of probiotic supplementation to fish. Bioflocs are rich in various probiotics and bioactive compounds and their effects on juvenile sea cucumber Apostichopus japonicus have been analyzed [131]. From an immunological point of view, biofloc increased phagocytosis and respiratory burst in comparison to untreated fish, also upregulating immune-related genes such as heat shock proteins $[90,70,105]$, rel, nitric oxidase and lysozyme. In treated fish challenged with Vibrio splendidus, mortality significantly decreased in comparison to controls. Lactobacillus (L.) delbrueckii administration to Cyprinus carpio huanghe var has recently been investigated to evaluate resistance against Aeromonas (A.) hydrophila [132]. Results have demonstrated that $L$. delbrueckii supplementation upregulated lysozyme, acid phosphatase and myeloperoxidase activities and antioxidant enzymes [superoxide dismutase (SOD), catalase, gluthatione peroxidase)], while downregulating mRNA levels of IL-1 $\beta$, IL-8, TNF- $\alpha$ and NF- $\kappa B$ $\mathrm{p} 65$. In view of these effects growth performance and survival rate improved. In another study, two recombinant L. casei (surfacedisplayed or secretory) expressing the OmpAI of $A$. veronii were administered to Cyprinus carpio challenged with $A$. veronii [133]. In comparison to untreated fish after $A$. veronii infection, fish fed with recombinant $L$. casei exhibited higher titers of serum and skin mucus antibodies, lysozymes and gene expression of IL- $1 \beta$, IFN- $\gamma$, IL-10 and TNF- $\alpha$. Immune modifications positively correlated with higher survival in treated fish in comparison to controls.

In view of the beneficial effects exerted by pre- and probiotics when independently administered to fish, their association, the socalled synbiotics, has also been experimented in fish. As extensively reviewed by Huynh and associates [134], synbiotics administration to fish increased nutritional absorptive capacities, on the one hand, and, increased natural and adaptive immune responses on the other hand. Besides that, synbiotics were able to modify intestinal microbiota in Apostichopus japonicus during vibrio infection, increasing proportions of Bacillus and Lactococcus in comparison to controls [135].

\section{2. $\beta$-Glucans}

$\beta$-glucans are natural polysaccharides largely produced by bacteria, fungi and yeast [136]. $\beta$-glucans act through a specific receptor dectin-1 (not yet well defined in fish) and TLR-2 on leukocytes [137]. Activation of dectin-1 triggers intracellular signaling, e.g., Syk/NF- $\kappa B$ pathways, thus, leading to increased expression of immune genes and release of pro-inflammatory cytokines (IL-1, IL-8, IL-12, TNF- $\alpha$ ). $\beta$-glucans are profusely used in aquaculture for their beneficial effects on the immune system and increased resistance to stress. In cod larvae, $\beta$-glucans have been administered via encapsulation by live food [138]. Mostly, $\beta$-glucans extracted from diatoms were very effective in survival and growth. In a recent study [139], Sterigmatomyces halophilus $\beta$-glucans, when administered to pacific red snapper, increased phagocytic activity, respiratory burst, NO production, SOD and catalase activities and immune genes for IL-1 $\beta$, IL-10 and IL-17. This led to an increased resistance against $A$. hydrophila. Similar protective effects were observed in Oreochromis niloticus challenged with Staphylococcus iniae [140]. Increase in anti-oxidant, anti-inflammatory, anti-stress and immune-related genes contributed to the protective effect against bacterial infections. Furthermore, in an in vitro model, fungal $\beta$-glucans increased in head-kidney leukocytes from pacific red snapper NO production, myeloperoxidase, SOD and catalase activities as well as induction of pro-inflammatory cytokines [141].

\subsection{Lipids}

There is a large body of evidence that polyunsaturated fatty acids (PUFAs), when ingested with food or as supplements exert 
beneficial effects to the host, even including the switch-on of an intestinal immune tolerogenic pathway and the improvement of gut microbiota [142, 143]. In farmed fish, a few experimentations with PUFAs have been conducted in order to promote growth of healthy fish despite pollution, overcrowding and risk of infections. In a recent report [144], rainbow trout juveniles were administered with four PUFAs, namely, $\alpha$-linoleic (ALA), linoleic acid (LA), eicosapentaenoic acid (EPA) and docosahexaenoic acid (DHA). All four PUFAs were combined with an environmentally-realistic concentration of cadmium. Some fish were challenged with A. salmonicida at the end of cadmium conditioning period. Despite the fact that cadmium even at low doses could down-regulate the fish immune response, PUFA administration improved growth (DHA), protected against oxidative stress (ALA and EPA) and enhanced innate immunity. Hepatic steatosis frequently occurs in farmed fish, ultimately leading to severe inflammation. In large yellow croaker, administration of omega-3 PUFAs mitigated liver steatosis-induced inflammation [145]. The protective mechanism exerted by omega- 3 seems to rely on the sirtuin-1-mediated nuclear translocation of NF$\kappa \mathrm{B}$ p65 subunit in hepatocytes.

Arachidonic acid supplemented to rabbit fish Siganus rivulatus during an outbreak of $S$. iniae prolonged survival in comparison to controls, while increasing lysozyme, complement and total serum Ig levels [146]. Conclusively, this regimen could improve growth survival and immune functions.

$\alpha$-lipoic acid ( $\alpha$-LA) when supplemented to grass carp has been demonstrated to prevent omega-3-induced lipid peroxidation [147]. In fact, in grass carp omega-3 dietary regimen could increase production of malondialdehyde, thus, inducing lipid peroxidation in liver and muscle. This $\alpha$-LA-mediated effect was based on the increased expression of NF-E2-related nuclear factor 2 and decrease of kelch-like-ECH-associated protein $1 \mathrm{mRNA}$ levels.

Sodium butyrate (SB) administration to young grass carp enhanced intestinal immune function associated with NF- $\mathrm{KB}$ and p38 MAPK signaling [148]. In general, SB ameliorated growth performance, intestinal growth and function, increasing the number of Lactobacilli in the gut microbiota. In particular, either natural immunity (increase in $\mathrm{C} 3$ and $\mathrm{C} 4, \mathrm{IgM}$ and antimicrobial peptides) or adaptive immunity (increase in anti-inflammatory cytokines) were modulated by SB.

\subsection{Vitamins}

Vitamins are essential micronutrients endowed with multiple immune functions in animals and humans. In an in vitro study, using the rainbow trout monocyte-macrophage cell line RT811 and head-kidney leukocytes vitamin $\mathrm{C}$ increased production of phagocytic cell number [149]. Furthermore, vitamin C also enhanced the transcription of several pro-inflammatory and antimicrobial genes triggered by Escherichia coli. Of note, evidence has been provided that vitamin $\mathrm{C}$ attenuates the toxic effects of $17 \alpha$-methyltestosterone, reducing up-regulation of pro-inflammatory cytokines, chemokines, TLR-7, IgM and apoptosis [150]. Finally, as recently reviewed by Dawood and Koshio [151] vitamin C is essential for growth health and stress resistance in fish.

In European sea bass administered with vitamin D3 an increase in phagocytic capacities was observed [152]. In head-kidney and gut, increase in fbl and rbl transcripts and hep gene, respectively, were detected.

Vitamin E effects on fish have also been investigated. In turbot fed high-fat diet vitamin $\mathrm{E}$ administration prevented induction of hepatic oxidative stress [153]. Furthermore, increase in non-specific immunity and modulation of inflammatory genes was documented. In Tilapia nilotica, vitamin E supplementation attenuated the ZnONPs-mediated oxidative stress [154]. In particular, ZnONPs administration in the absence of vitamin $E$ increased alanine transaminase, aspartate transaminase and alkaline phosphatase ac- tivities and generated oxidative stress inhibiting SOD and catalase activities. In Chinese mitten crab fed the diet with fish oil and vitamin E improved growth and anti-oxidant functions along with high resistance to A. hydrophila were observed [155]. In Anguilla japon$i c a$, dietary vitamin $\mathrm{E}$ led to higher hemoglobin concentration and white blood cell numbers also increasing lysozyme and SOD activity [156].

\subsection{Polyphenols}

Polyphenols are natural products largely present in the vegetal kingdom and, especially, in vegetables, fruits, cereals and beverages such as wine, tea, chocolate and juices [157]. Structurally, polyphenols can be divided into flavonoids and non-flavonoids (e.g., resveratrol) compounds [158]. Numerous reports have firmly confirmed the anti-oxidant and anti-inflammatory abilities of polyphenols. In the last decade, our own group has documented the efficacy of polyphenols extracted from red wine or fermented grape marc to exert anti-inflammatory activities, promoting a tolerogenic pathway either in vitro or in vivo in experimental models and humans [155-168]. Also in farmed fish polyphenols have been used as supplement to conventional feed. In gold fish, subjected to a hypercholesterolemic diet, administration of polyphenols derived from waste water from an olive mill reduced steatotic damage [169]. In farmed turbot, resveratrol administration prevented the outcome of Scutociliatosis, exerting potent anti-protozoal activity against the Hystiophagous ciliate Philasterides dicentrarchi [170]. In this framework, in juvenile GIFT tilapia administration of resveratrol at higher doses $(0.3 \mathrm{~g} / \mathrm{kg})$ induced hepatic damage and intestinal deformation in comparison to the lower doses $(0.1 \mathrm{~g} / \mathrm{kg})$ [171]. In zebrafish, caffeic acid and hydroxytyrosol prevented the obesogenic effect generated by the peroxisome proliferator-activated receptor $\gamma$ agonist, rosiglitazone [172]. In the same test system, both compounds prevented lipid accumulation in primary-cultured rainbow trout adipocytes with hydroxytyrosol suppressing the mRNA levels of the fasn gene in the adipose tissue of this fish. In another report, farmed European sea bass juveniles have been administered with polyphenols extracted from red grape (Canosina Nero di Troia, Vitis vinifera) at two different concentrations (100 and $200 \mathrm{mg} / \mathrm{kg}$ ) [173]. Fish were evaluated for gut and splenic cytokine release and MMCs areas and distribution. A decrease in intestinal IL-1 $\beta$ and IL-6 release with an increase in MMCs areas was observed. Conclusively, following administration of polyphenols, reduction of pro-inflammatory cytokines and increase in protective natural immunity and adaptive immune response (splenic IFN- $\gamma$ ) led to a reduced fish mortality in comparison to controls. Using the same dietary regimen, polyphenols led to an expansion of farmed sea bass hepatopancreas, which may have contributed to reduced mortality [174]. In Table $4 *$ major interventions with natural products in farmed fish are summarized.

\section{CONCLUSION AND FUTURE PERSPECTIVES}

As extensively discussed in the previous sections of this review, fish mortality in aquaculture is still high due to stressful conditions and mostly infectious agents. As recently reviewed by Mweemba Munang'Andu and associates [175], genomic studies have been applied to farmed fish for discovering new pathogens, genes linked to disease resistance and innovative approaches to control and prevent piscine disease. For instance, hepcidin-like antimicrobial peptides (Th1-5, Th2-2, and Th2-3) have been identified in tilapia, using phage hybridization [176]. Hepcidin has been shown to exhibit antimicrobial activities against a wide range of extracellular and intracellular bacteria and viruses in many fish either in vitro or in vivo [177-180]. Recombinant IFNs and, especially, IFN- $\alpha 2$ have been shown to be protective against viruses in rainbow trout, even if immunity had a short duration [181]. IFN encapsulated in nanoparticles when administered to fish increased relative percent survival against nervous necrosis virus infection [182]. However, in Atlantic salmon infectious pancreatic necrosis virus could replicate 
Table 4. Dietary products administered to farmed fish.

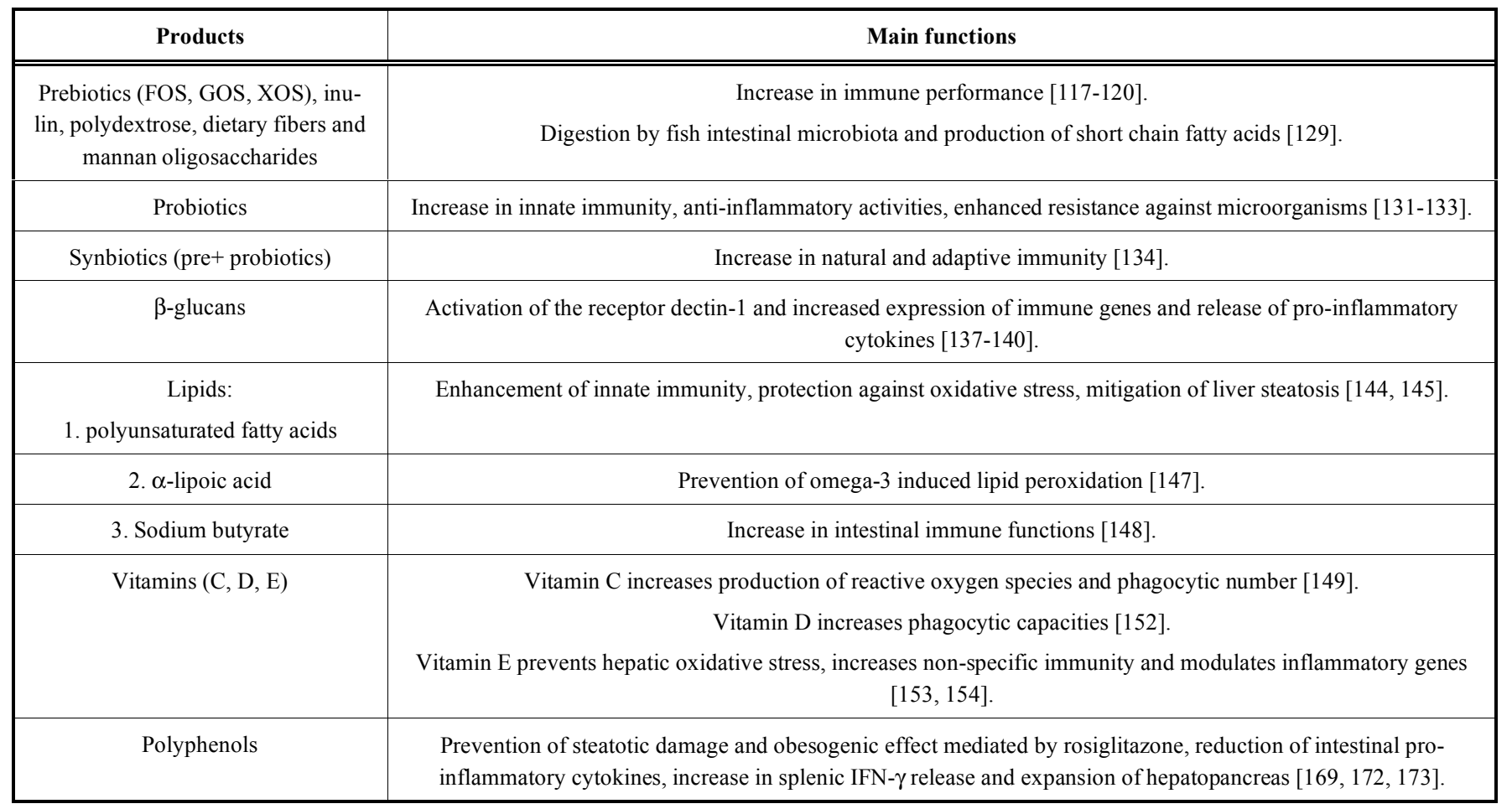

*Further details have been added in the text

at higher rate despite the presence of type I IFN [183]. In synthesis, according to Ooi and associates and $\mathrm{Xu}$ and associates [182, 184], type I IFNs are able to induce the expression of antiviral genes, also activating signaling pathways, which, in turn, generate other antiviral genes in fish. Our group has recently contributed to the issue of better health of farmed fish demonstrating that conventional feeds enriched in polyphenols (extracted from seeds of red grapes) improve the gut immune response also decreasing mortality in sea bass (Dicentrarchus Labrax L.) [173]. Furthermore, in these fish the same dietary regimen increased the size and morphology of hepatopancreas, thus, further contributing to fish health [174]. Conclusively, all the above cited data are representative of the current studies aimed at preventing and controlling farmed fish disease.

\section{LIST OF ABBREVIATIONS}

\begin{tabular}{|c|c|c|}
\hline$\alpha-\mathrm{LA}$ & $=$ & $\alpha$-lipoic acid \\
\hline ALA & $=$ & $\alpha$-linoleic \\
\hline APCs & $=$ & Antigen presenting cells \\
\hline $\mathrm{CSF}$ & $=$ & Colony stimulating factor \\
\hline DCs & $=$ & Dendritic cells \\
\hline DHA & $=$ & Docosahexaenoic acid \\
\hline EPA & $=$ & Eicosapentaenoic acid \\
\hline FOS & $=$ & Fructose oligosaccharides \\
\hline GCs & $=$ & Germinal centers \\
\hline GIALT & $=$ & Gill-associated lymphoid tissue \\
\hline GOS & $=$ & Galactose oligosaccharides \\
\hline $\mathrm{ICs}$ & $=$ & Immune complexes \\
\hline IDO & $=$ & Indoleamine 2,3-dioxygenase \\
\hline IFN & $=$ & Interferon \\
\hline $\operatorname{Ig}$ & $=$ & Immunoglobulin \\
\hline IELs & $=$ & Intraepithelial lymphocytes \\
\hline
\end{tabular}

$\begin{array}{lll}\mathrm{IL} & = & \text { Interleukin } \\ \mathrm{LA} & = & \text { Linoleic acid } \\ \text { LPS } & = & \text { Lipopolysaccharides } \\ \text { MALTs } & = & \text { Mucosa-associated lymphoid tissue } \\ \text { MHC } & = & \text { Major histocompatibility complex } \\ \text { MMCs } & = & \text { Melanomacrophage centers } \\ \text { NLRs } & = & \text { Nucleotide-binding domain-leucine-rich repeat } \\ \text { NO } & = & \text { Nitric oxide } \\ \text { PRRs } & = & \text { Pattern recognition receptors } \\ \text { PUFAs } & = & \text { Polyunsaturated fatty acids } \\ \text { RAG } & = & \text { Recombinant-activating gene } \\ \text { SB } & = & \text { Sodium butyrate } \\ \text { SCFAs } & = & \text { Short fatty acids } \\ \text { SOD } & = & \text { Superoxide dismutase } \\ \text { TCR } & = & \text { T cell receptor } \\ \text { Th } & = & \text { T helper } \\ \text { TLRs } & = & \text { Toll-like receptors } \\ \text { TNF } & = & \text { Tumor necrosis factor } \\ \text { Treg } & =\text { T regulatory } \\ \text { XOS } & =\text { Xylose oligosaccharides }\end{array}$

\section{CONFLICT OF INTEREST} wise.

The authors declare no conflict of interest, financial or other-

\section{ACKNOWLEDGEMENTS}

This paper was supported by Regione Puglia-project Vis Maris (Bando FESR 2007-13-Azione 1.2.4 Bando "Aiuti a Sostegno dei Partenariati Regionali per l'Innovazione"). 
Thea Magrone is a recipient of the grant "Intervento cofinanziato dal Fondo di Sviluppo e Coesione 2007-2013-APQ Ricerca Regione Puglia Programma regionale a sostegno della specializzazione intelligente e della sostenibilità sociale ed ambientaleFutureInResearch"
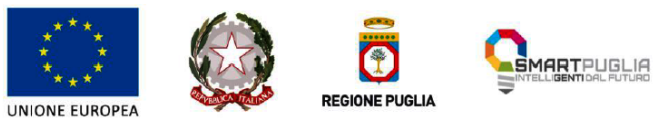

$-\mathbf{a} \cdot \mathbf{r} \cdot \mathbf{t} \cdot \mathbf{i}$ Agenzia regionale
per la tecnologia l'innovazione

\section{REFERENCES}

[1] Salinas I. The Mucosal Immune System of Teleost Fish. Biology (Basel) 2015; 4(3): 525-39.

[2] van der Marel M, Caspari N, Neuhaus H, Meyer W, Enss ML, Steinhagen D. Changes in skin mucus of common carp, Cyprinus carpio L., after exposure to water with a high bacterial load. J Fish Dis 2010; 33(5): 431-9.

[3] Estensoro I, Jung-Schroers V, Álvarez-Pellitero P, Steinhagen D, Sitjà-Bobadilla A. Effects of Enteromyxum leei (Myxozoa) infection on gilthead sea bream (Sparus aurata) (Teleostei) intestinal mucus: glycoprotein profile and bacterial adhesion. Parasitol Res 2013; $112(2): 567-76$.

[4] Jirillo F, Passantino G, Massaro MA, et al. In vitro elicitation of intestinal immune responses in teleost fish: evidence for a type IV hypersensitivity reaction in rainbow trout. Immunopharmacol Immunotoxicol 2007; 29(1): 69-80.

[5] Haugarvoll E, Bjerkås I, Nowak BF, Hordvik I, Koppang EO. Identification and characterization of a novel intraepithelial lymphoid tissue in the gills of Atlantic salmon. J Anat 2008; 13(2): 202-9.

[6] Falk K, Press CM, Landsverk T, Dannevig BH. Spleen and kidney of Atlantic salmon (Salmo salar L.) show histochemical changes early in the course of experimentally induced infectious salmon anaemia (ISA). Vet Immunol Immunopathol 1995; 49(1-2): 115-26.

[7] Press McL C, Dannevig B.H., Landsverk T. Immune and enzyme histochemical phenotypes of lymphoid and nonlymphoid cells within the spleen and head kidney of Atlantic salmon (Salmo salar L.). Fish Shellfish Immunol 1994; 4(2): 79-93.

[8] Bermúdez R, Vigliano F, Marcaccini A, Sitjà-Bobadilla A, Quiroga MI, Nieto JM. Response of Ig-positive cells to Enteromyxum scophthalmi (Myxozoa) experimental infection in turbot, Scophthalmus maximus (L.): A histopathological and immunohistochemical study. Fish Shellfish Immunol 2006; 21(5): 501-12.

[9] Agius C, Roberts RJ. Melano-macrophage centres and their role in fish pathology. J Fish Dis 2003; 26(9): 499-509.

[10] Rieger AM, Hall BE, Barreda DR. Macrophage activation differentially modulates particle binding, phagocytosis and downstream antimicrobial mechanisms. Dev Comp Immunol 2010; 34(11): 114459.

[11] Anderson HL, Brodsky IE, Mangalmurti NS. The Evolving Erythrocyte: Red Blood Cells as Modulators of Innate Immunity. J Immunol 2018; 201(5): 1343-51.

[12] Fuglem B, Jirillo E, Bjerkås I, et al. Antigen-sampling cells in the salmonid intestinal epithelium. Dev Comp Immunol 2010; 34(7): 768-74.

[13] Passantino L, Altamura M, Cianciotta A, et al. Fish immunology. I. Binding and engulfment of Candida albicans by erythrocytes of rainbow trout (Salmo gairdneri Richardson). Immunopharmacol Immunotoxicol 2002; 24(4): 665-78.

[14] Passantino L, Tafaro A, Altamura M, Arena R, Passantino GF, Jirillo E. Fish immunology. II. Morphologycal and cytochemical characterization and phagocytic activities of head kidney macrophages from rainbow trout (Salmo gairdneri Richardson). Immunopharmacol Immunotoxicol 2002; 24(4): 679-91.

[15] Passantino L, Altamura M, Cianciotta A, et al. Maturation of fish erythrocytes coincides with changes in their morphology, enhanced ability to interact with Candida albicans and release of cytokine-like factors active upon autologous macrophages. Immunopharmacol Immunotoxicol 2004; 26(4): 573-85.

[16] Passantino L, Cianciotta A, Jirillo F, et al. Lymphoreticular system in fish: erythrocyte-mediated immunomodulation of macrophages contributes to the formation of melanomacrophage centers. Immunopharmacol Immunotoxicol 2005; 27(1): 147-61.
[17] Passantino L, Cianciotta A, Patruno R, Ribaud MR, Jirillo E, Passantino GF. Do fish thrombocytes play an immunological role? Their cytoenzymatic profiles and function during an accidental piscine candidiasis in aquarium. Immunopharmacol Immunotoxicol 2005; 27(2): 345-56.

[18] Matsunaga T, Rahman A. In search of the origin of the thymus: the thymus and GALT may be evolutionarily related. Scand J Immunol 2001; 53(1): 1-6.

[19] Flajink MF. A convergent immunological holy trinity of adaptive immunity in lampreys: Discovery of the variable lymphocytes receptors. J Immunol 2018; 201(5): 1331-5.

[20] Peaudecerf L, Rocha B. Role of the gut as a primary lymphoid organ. Immunol Lett 2011; 140(1-2): 1-6.

[21] Xiao X, Cai J. Mucosal-Associated Invariant T Cells: New Insights into Antigen Recognition and Activation. Front Immunol 2017; 8: 1540 .

[22] Takizawa F, Araki K, Kobayashi I, Moritomo T, Ototake M, Nakanishi T. Molecular cloning and expression analysis of T-bet in ginbuna crucian carp (Carassius auratus langsdorfii). Mol Immunol 2008; 45(1): 127-36.

[23] Leal E, Granja AG, Zarza C, Tafalla C. Distribution of T Cells in Rainbow Trout (Oncorhynchus mykiss) Skin and Responsiveness to Viral Infection. PLoS ONE 2016; 11(1): e0147477.

[24] Sepahi A, Casadei E, Tacchi L, Muñoz P, LaPatra SE, Salinas I. Tissue Microenvironments in the Nasal Epithelium of Rainbow Trout (Oncorhynchus mykiss) Define Two Distinct CD8 $\alpha+$ Cell Populations and Establish Regional Immunity. J Immunol 2016; 197(11): 4453-63.

[25] Zhang YA, Salinas I, Li J, et al. IgT, a primitive immunoglobulin class specialized in mucosal immunity. Nat Immunol 2010; 11(9): 827-35.

[26] Pickering AD, Pottinger TG. Stress responses and disease resistance in salmonid fish: Effects of chronic elevation of plasma cortisol. Fish Physiol Biochem 1989; 7(1-6): 253-8.

[27] Parra D, Reyes-Lopez FE, Tort L. Mucosal Immunity and B Cells in Teleosts: Effect of Vaccination and Stress. Front Immunol 2015; 6: 354 .

[28] Estévez RA, Mostazo MGC, Rodriguez E, et al. Inducers of salmon innate immunity: An in vitro and in vivo approach. Fish Shellfish Immunol 2018; 72: 247-58.

[29] Agius C. The role of melano-macrophage centres in iron storage in normal and diseased fish. J Fish Dis 1979; 2: 337-43.

[30] Klei TRL, Meinderts SM, van den Berg TK, van Bruggen R. From the cradle to the grave: the role of macrophages in erythropoiesis and erythrophagocytosis. Front Immunol 2017; 8: 73.

[31] Vogelbein WK, Fournie JW. Sequential development and morphology of experimentally induced hepatic melano-macrophage centres in Rivulus marmoratus. J Fish Biol 1987; 31: 145-53.

[32] Brattgjerd S, Evensen O. A sequential light microscopic and ultrastructural study on the uptake and handling of Vibrio salmonicida in phagocytes of the head kidney in experimentally infected Atlantic salmon (Salmo salar L.). Vet Pathol 1996; 33: 55-65.

[33] Ferguson HW. The relationship between ellipsoids and melanomacrophage centres in the spleen of turbot (Scophthalmus maximus). J Comp Pathol 1976; 86: 377-80.

[34] Solem ST, Stenvik J. Antibody repertoire development in teleosts-a review with emphasis on salmonids and Gadus morhua L. Dev Comp Immunol 2006; 30(1-2): 57-76.

[35] Kaattari SL, Zhang HL, Khor IW, Kaattari IM, Shapiro DA. Affinity maturation in trout: clonal dominance of high affinity antibodies late in the immune response. Dev Comp Immunol 2002; 26(2): 191200.

[36] Lamers CH, De Haas MJ. Antigen localization in the lymphoid organs of carp (Cyprinus carpio). Cell Tissue Res 1985; 242(3): 491-8.

[37] Secombes CJ, Manning MJ. Comparative studies on the immunesystem of fishes and amphibians-antigen localization in the carp Cyprinus carpio L. J Fish Dis 1980; 3: 399-412.

[38] Secombes CJ, Manning MJ, Ellis AE. Localization of immune complexes and heat-aggregated immunoglobulin in the carp Cyprinus carpio L. Immunology 1982; 47(1): 101-5.

[39] Victora GD, Nussenzweig MC. Germinal centers. Annu Rev Immunol 2012; 30: 429-57.

[40] Steinel NC, Bolnick DI. Melanomacrophage Centers As a Histological Indicator of Immune Function in Fish and Other Poikilotherms. Front Immunol 2017; 8: 827. 
[41] Zhou D, Huang C, Lin Z, et al. Macrophage polarization and function with emphasis on the evolving roles of coordinated regulation of cellular signaling pathways. Cell Signal 2014; 26(2): 192-7.

[42] Barreda DR, Neumann NF, Belosevic M. Flow cytometric analysis of PKH26-labeled goldfish kidney-derived macrophages. Dev Comp Immunol 2000; 24(4): 395-406.

[43] Neumann NF, Stafford JL, Belosevic M. Biochemical and functional characterisation of macrophage stimulating factors secreted by mitogen-induced goldfish kidney leucocytes. Fish Shellfish Immunol 2000; 10(2): 167-86.

[44] Mills CD, Ley K. M1 and M2 macrophages: the chicken and the egg of immunity. J Innate Immun 2014; 6(6): 716-26.

[45] Joerink M, Forlenza M, Ribeiro CM, de Vries BJ, Savelkoul HF, Wiegertjes GF. Differential macrophage polarisation during parasitic infections in common carp (Cyprinus carpio L.). Fish Shellfish Immunol 2006; 21(5): 561-71.

[46] Grayfer L, Hodgkinson JW, Hitchen SJ, Belosevic M. Characterization and functional analysis of goldfish (Carassius auratus L.) interleukin-10. Mol Immunol 2011; 48(4): 563-71.

[47] Castro R, Zou J, Secombes CJ, Martin SA. Cortisol modulates the induction of inflammatory gene expression in a rainbow trout macrophage cell line. Fish Shellfish Immunol 2011; 30(1): 215-23.

[48] Wang T, Hanington PC, Belosevic M, Secombes CJ. Two macrophage colony-stimulating factor genes exist in fish that differ in gene organization and are differentially expressed. J Immunol 2008; 181(5): 3310-22.

[49] Grayfer L, Hanington PC, Belosevic M. Macrophage colonystimulating factor (CSF-1) induces pro-inflammatory gene expression and enhances antimicrobial responses of goldfish (Carassius auratus L.) macrophages. Fish Shellfish Immunol 2009; 26(3): 40613.

[50] Williams H, Brenner S, Venkatesh B. Identification and analysis of additional copies of the platelet-derived growth factor receptor and colony stimulating factor 1 receptor genes in fugu. Gene 2002; 295(2): 255-64.

[51] Hansen JD, Vojtech LN, Laing KJ. Sensing disease and danger: a survey of vertebrate PRRs and their origins. Dev Comp Immunol 2011; 35(9): 886-97.

[52] Roach JC, Glusman G, Rowen L, et al. The evolution of vertebrate Toll-like receptors. Proc Natl Acad Sci U S A 2005; 102(27): 957782.

[53] Oshiumi H, Matsuo A, Matsumoto M, Seya T. Pan-vertebrate tolllike receptors during evolution. Curr Genomics 2008; 9(7): 488-93.

[54] Sepulcre MP, Alcaraz-Pérez F, López-Muñoz A, et al. Evolution of lipopolysaccharide (LPS) recognition and signaling: fish TLR4 does not recognize LPS and negatively regulates NF-kappaB activation. J Immunol 2009; 182(4): 1836-45.

[55] Xie J, Hodgkinson JW, Katzenback BA, Kovacevic N, Belosevic M. Characterization of three Nod-like receptors and their role in antimicrobial responses of goldfish (Carassius auratus L.) macrophages to Aeromonas salmonicida and Mycobacterium marinum. Dev Comp Immunol 2013; 39(3): 180-7.

[56] Angosto D, López-Castejón G, López-Muñoz A, et al. Evolution of inflammasome functions in vertebrates: Inflammasome and caspase-1 trigger fish macrophage cell death but are dispensable for the processing of IL-1 $\beta$. Innate Immun 2012; 18(6): 815-24.

[57] Iyengar R, Stuehr DJ, Marletta MA. Macrophage synthesis of nitrite, nitrate, and N-nitrosamines: precursors and role of the respiratory burst. Proc Natl Acad Sci U S A 1987; 84(18): 6369-73.

[58] Wang XF, Wang HS, Wang H, et al. The role of indoleamine 2,3dioxygenase (IDO) in immune tolerance: focus on macrophage polarization of THP-1 cells. Cell Immunol 2014; 289(1-2): 42-8.

[59] Grohmann U, Bronte V. Control of immune response by amino acid metabolism. Immunol Rev 2010; 236: 243-64.

[60] Yoshida R, Imanishi J, Oku T, Kishida T, Hayaishi O. Induction of pulmonary indoleamine 2,3-dioxygenase by interferon. Proc Natl Acad Sci U S A 1981; 78(1): 129-32.

[61] Takizawa F, Koppang EO, Ohtani M, et al. Constitutive high expression of interleukin-4/13A and GATA-3 in gill and skin of salmonid fishes suggests that these tissues form Th2-skewed immune environments. Mol Immunol 2011; 48(12-13): 1360-8.

[62] Wang T, Johansson P, Abós B, et al. First in-depth analysis of the novel Th2-type cytokines in salmonid fish reveals distinct patterns of expression and modulation but overlapping bioactivities. Oncotarget 2016; 7(10): 10917-46.
[63] Grayfer L, Hodgkinson JW, Belosevic M. Analysis of the antimicrobial responses of primary phagocytes of the goldfish (Carassius auratus L.) against Mycobacterium marinum. Dev Comp Immunol 2011; 35(11): 1146-58

[64] Wright PA, Campbell A, Morgan RL, Rosenberger AG, Murray BW. Dogmas and controversies in the handling of nitrogenous wastes: expression of arginase Type I and II genes in rainbow trout: influence of fasting on liver enzyme activity and mRNA levels in juveniles. J Exp Biol 2004; 207(Pt 12): 2033-42.

[65] Mills CD. Macrophage arginine metabolism to ornithine/urea or nitric oxide/citrulline: a life or death issue. Crit Rev Immunol 2001; 21(5): 399-425

[66] Joerink M, Ribeiro CM, Stet RJ, Hermsen T, Savelkoul HF, Wiegertjes GF. Head kidney-derived macrophages of common carp (Cyprinus carpio L.) show plasticity and functional polarization upon differential stimulation. J Immunol 2006; 177(1): 61-9.

[67] Grimholt U. Whole genome duplications have provided teleosts with many roads to peptide loaded MHC class I molecules. BMC Evol Biol 2018; 18(1): 25.

[68] Star B, Jentoft S. Why does the immune system of Atlantic cod lack MHC II? Bioessays 2012; 34(8): 648-51.

[69] Haase D, Roth O, Kalbe M, et al. Absence of major histocompatibility complex class II mediated immunity in pipefish, Syngnathus typhle: evidence from deep transcriptome sequencing. Biol Lett 2013; 9(2): 20130044.

[70] Johansson P, Corripio-Miyar Y, Wang T, Collet B, Secombes CJ, Zou J. Characterisation and expression analysis of the rainbow trout (Oncorhynchus mykiss) homologue of the human dendritic cell marker CD208/lysosomal associated membrane protein 3. Dev Comp Immunol 2012; 37(3-4): 402-13.

[71] Soleto I, Fischer U, Tafalla C, Granja AG. Identification of a Potential Common Ancestor for Mammalian Cross-Presenting Dendritic Cells in Teleost Respiratory Surfaces. Front Immunol 2018; 9: 59.

[72] Shao T, Zhu LY, Nie L, et al. Characterization of surface phenotypic molecules of teleost dendritic cells. Dev Comp Immunol 2015; 49(1): 38-43.

[73] Scapigliati G, Fausto AM, Picchietti S. Fish Lymphocytes: An Evolutionary Equivalent of Mammalian Innate-Like Lymphocytes? Front Immunol 2018; 9: 971.

[74] Wu Y, Wu W, Wong WM, et al. Human gamma delta T cells: a lymphoid lineage cell capable of professional phagocytosis. J Immunol 2009; 183(9): 5622-9.

[75] Wan F, Hu CB, Ma JX, Gao K, Xiang LX, Shao JZ. Characterization of $\gamma \delta$ T Cells from Zebrafish Provides Insights into Their Important Role in Adaptive Humoral Immunity. Front Immunol 2017; 7: 675 .

[76] Born WK, Yin Z, Hahn YS, Sun D, O'Brien RL. Analysis of gamma delta $\mathrm{T}$ cell functions in the mouse. J Immunol 2010 ; 184(8): 4055-61.

[77] Corpuz TM, Stolp J, Kim HO, et al. Differential Responsiveness of Innate-like IL-17- and IFN- $\gamma$-Producing $\gamma \delta$ T Cells to Homeostatic Cytokines. J Immunol 2016; 196(2): 645-54.

[78] Tung JW, Mrazek MD, Yang Y, Herzenberg LA, Herzenberg LA. Phenotypically distinct B cell development pathways map to the three B cell lineages in the mouse. Proc Natl Acad Sci U S A 2006; 103(16): 6293-8.

[79] Gao J, Ma X, Gu W, et al. Novel functions of murine B1 cells: active phagocytic and microbicidal abilities. Eur J Immunol 2012; 42(4): 982-92.

[80] Milner EC, Anolik J, Cappione A, Sanz I. Human innate B cells: a link between host defense and autoimmunity? Springer Semin Immunopathol 2005; 26(4): 433-52.

[81] Nakanishi T, Toda H, Shibasaki Y, Somamoto T. Cytotoxic T cells in teleost fish. Dev Comp Immunol 2011; 35(12): 1317-23.

[82] Takizawa F, Magadan S, Parra D, et al. Novel Teleost CD4-Bearing Cell Populations Provide Insights into the Evolutionary Origins and Primordial Roles of CD4+ Lymphocytes and CD4+ Macrophages. J Immunol 2016; 196(11): 4522-35.

[83] Kasheta M, Painter CA, Moore FE, et al. Identification and characterization of T reg-like cells in zebrafish. J Exp Med 2017; 214(12): 3519-30.

[84] Buonocore F, Castro R, Randelli E, et al. Diversity, molecular characterization and expression of $\mathrm{T}$ cell receptor $\gamma$ in a teleost fish, the sea bass (Dicentrarchus labrax, L). PLoS One 2012; 7(10): e47957. 
[85] Bernard D, Six A, Rigottier-Gois L, et al. Phenotypic and functional similarity of gut intraepithelial and systemic $\mathrm{T}$ cells in a teleost fish. J Immunol 2006; 176(7): 3942-9.

[86] Nuñez Ortiz N, Gerdol M, Stocchi V, et al. T cell transcripts and T cell activities in the gills of the teleost fish sea bass (Dicentrarchus labrax). Dev Comp Immunol 2014; 47(2): 309-18.

[87] Boschi I, Randelli E, Buonocore F, et al. Transcription of T cellrelated genes in teleost fish, and the European sea bass (Dicentrarchus labrax) as a model. Fish Shellfish Immunol 2011; 31(5): 655-62.

[88] Sugimoto K, Hui SP, Sheng DZ, Nakayama M, Kikuchi K. Zebrafish FOXP3 is required for the maintenance of immune tolerance. Dev Comp Immunol 2017; 73: 156-62.

[89] Hui SP, Sheng DZ, Sugimoto K, et al. Zebrafish Regulatory T Cells Mediate Organ-Specific Regenerative Programs. Dev Cell 2017; 43(6): 659-72.e5.

[90] Aas IB, Austbø L, Falk K, Hordvik I, Koppang EO. The interbranchial lymphoid tissue likely contributes to immune tolerance and defense in the gills of Atlantic salmon. Dev Comp Immunol 2017; 76: 247-54.

[91] Danilova N, Steiner LA. B cells develop in the zebrafish pancreas. Proc Natl Acad Sci U S A 2002; 99(21): 13711-6.

[92] Rombout JH, Huttenhuis HB, Picchietti S, Scapigliati G. Phylogeny and ontogeny of fish leucocytes. Fish Shellfish Immunol 2005; 19(5): 441-55.

[93] Flajnik MF. A cold-blooded view of adaptive immunity. Nat Rev Immunol 2018; 18(7): 438-53.

[94] Malmstrøm M, Matschiner M, Tørresen OK, et al. Evolution of the immune system influences speciation rates in teleost fishes. Nat Genet 2016; 48(10): 1204-10.

[95] Xu Z, Takizawa F, Parra D, et al. Mucosal immunoglobulins at respiratory surfaces mark an ancient association that predates the emergence of tetrapods. Nat Commun 2016; 7: 10728.

[96] Picchietti S, Nuñez-Ortiz N, Stocchi V, et al. Evolution of lymphocytes. Immunoglobulin $\mathrm{T}$ of the teleost sea bass (Dicentrarchus labrax): Quantitation of gene expressing and immunoreactive cells. Fish Shellfish Immunol 2017; 63: 40-52.

[97] Chen K, Xu W, Wilson M, et al. Immunoglobulin D enhances immune surveillance by activating antimicrobial, proinflammatory and B cell-stimulating programs in basophils. Nat Immunol 2009; 10(8): 889-98.

[98] Abós B, Bird S, Granja AG, et al. Identification of the First Teleost CD5 Molecule: Additional Evidence on Phenotypical and Functional Similarities between Fish $\operatorname{IgM}^{+}$B Cells and Mammalian B1 Cells. J Immunol 2018; 201(2): 465-80.

[99] Yamaguchi T, Quillet E, Boudinot P, Fischer U. What could be the mechanisms of immunological memory in fish? What could be the mechanisms of immunological memory in fish? Fish Shellfish Immunol 2018; pii: S1050-4648(18)30035-4.

[100] Zou J, Carrington A, Collet B, et al. Identification and bioactivities of IFN-gamma in rainbow trout Oncorhynchus mykiss: the first Th1-type cytokine characterized functionally in fish. J Immunol 2005; 175(4): 2484-94.

[101] Savan R, Ravichandran S, Collins JR, Sakai M, Young HA. Structural conservation of interferon gamma among vertebrates. Cytokine Growth Factor Rev 2009; 20(2): 115-24.

[102] Grayfer L, Hodgkinson JW, Belosevic M. Analysis of the antimicrobial responses of primary phagocytes of the goldfish (Carassius auratus L.) against Mycobacterium marinum. Dev Comp Immunol 2011; 35(11): 1146-58.

[103] Grayfer L, Garcia EG, Belosevic M. Comparison of macrophage antimicrobial responses induced by type II interferons of the goldfish (Carassius auratus L.). J Biol Chem 2010; 285(31): 2353747.

[104] Kelly C, Salinas I. Under Pressure: Interactions between Commensal Microbiota and the Teleost Immune System. Front Immunol 2017; 8: 559

[105] Zhang Q, Gui JF. Virus genomes and virus-host interactions in aquaculture animals. Sci China Life Sci 2015; 58(2): 156-69.

[106] Roberts RJ. The bacteriology of teleost. In: Roberts RJ editor. Fish Pathol $4^{\text {th }}$ Ed. London, Wiley-Blackwell, 2012; pp.339-82.

[107] Sarker S, Kallert DM, Hedrick RP, El-Matbouli M. Whirling disease revisited: pathogenesis, parasite biology and disease intervention. Dis Aquat Organ 2015; 114(2): 155-75.

[108] Vadstein O, Bergh O, Gatesoupe F-J, et al. Microbiology and Immunology of fish larvae. Rev Aquacult 2013; 5(Suppl 1): S1-S25.
[109] Knappskog DH, Rodseth OM, Slinde E, Endresen C. Immunochemical analyses of Vibrio anguillarum strains isolated form cod (Gadus morhua L.) suffering from vibriosis. J Fish Dis 1993; 16: 327-38.

[110] Frans I, Michiels CW, Bossier P, Willems KA, Lievens B, Rediers $\mathrm{H}$. Vibrio anguillarum as a fish pathogen: virulence factors, diagnosis and prevention. J Fish Dis 2011; 34(9): 643-61.

[111] Silva YJ, Costa L, Pereira C, et al. Phage therapy as an approach to prevent Vibrio anguillarum infections in fish larvae production. PLoS One 2014; 9(12): e114197.

[112] Vadstein O. The use of immunostimulation in marine larviculture possibilities and challenges. Aqualculture 1197; 155 (1-4): 401-17.

[113] Sakai M. Current research status of fish immunostimulants. Aquaculture 1999; 172(1): 63-92.

[114] Mor A, Avtalion RR. Transfer of antibody activity from immunized mother to embryo in tilapias. J Fish Biol 1990; 37: 249-55.

[115] Bindels LB, Delzenne NM, Cani PD, Walter J. Towards a more comprehensive concept for prebiotics. Nat Rev Gastroenterol Hepatol $2015 ; 12(5): 303-10$.

[116] Guerreiro I, Couto A, Machado M, et al. Prebiotics effect on immune and hepatic oxidatyive status and gut morphology of white sea bream (Diplodus sorgus). Fish Shelfish Immunol 2016; 50: 16874.

[117] Wilson B, Whelan K. Prebiotic inulin-type fructans and galactooligosaccharides: definition, specificity, function, and application in gastrointestinal disorders. J Gastroenterol Hepatol 2017; 32(Suppl 1): 64-8.

[118] Hoseinifar SH, Ahmadi A, Raeisi M, Hoseini SM, Khalili M, Behnampour N. Comparative study on immunomodulatory and growth enhancing effects of three prebiotics (galactooligosaccharide, fructooligosaccharide and inulin) in common carp (Cyprinus carpio), Aquacult Res 2017; 48: 3298-3307.

[119] Hoseinifar SH, Zoheiri F, Dadar M, Rufchaei R, Ringø E. Dietary galactooligosaccharide elicits positive effects on non-specific immune parameters and growth performance in Caspian white fish (Rutilus frisii kutum) fry. Fish Shellfish Immunol 2016; 56: 467-72.

[120] Hoseinifar SH, Safari R, Dadar M. Dietary sodium propionate affects mucosal immune parameters, growth and appetite related genes expression: Insights from zebrafish model. Gen Comp Endocrinol 2017; 243: 78-83.

[121] Safari R, Hoseinifar SH, Kavandi M. Modulation of antioxidant defense and immune response in zebra fish (Danio rerio) using dietary sodium propionate. Fish Physiol Biochem 2016; 42(6): 1733-9.

[122] Yousefi S, Hoseinifar SH, Paknejad H, Hajimoradloo A. The effects of dietary supplement of galactooligosaccharide on innate immunity, immune related genes expression and growth performance in zebrafish (Danio rerio). Fish Shellfish Immunol 2018; 73 192-6.

[123] Di Bartolomeo F, Startek JB, Van den Ende W. Prebiotics to fight diseases: reality or fiction? Phytother Res 2013; 27(10): 1457-73.

[124] Shokryazdan P, Faseleh Jahromi M, Navidshad B, Liang JB. Effects of prebiotics on immune system and cytokine expression. Med Microbiol Immunol 2017; 206(1): 1-9.

[125] Hosseini M, Kolangi Miandare H, Shabani, Hoseinifar SH, Yarahmadi P. Dietary Lactobacillus acidophilus modulated skin mucus protein profile, immune and appetite genes expression in gold fish (Carassius auratus gibelio). Fish Shellfish Immunol 2016; 59: 14954 .

[126] Miandare HK, Farvardin S, Shabani A, Hoseinifar SH, Ramezanpour SS. The effects of galactooligosaccharide on systemic and mucosal immune response, growth performance and appetite related gene transcript in goldfish (Carassius auratus gibelio). Fish Shellfish Immunol 2016; 55: 479-83.

[127] Tan X, Sun Z, Zhou C, et al. Effects of dietary dandelion extract on intestinal morphology, antioxidant status, immune function and physical barrier function of juvenile golden pompano Trachinotus ovatus. Fish Shellfish Immunol 2018; 73: 197-206.

[128] Udayangani RMC, Dananjaya SHS, Nikapitiya C, Heo GJ, Lee J, De Zoysa M. Metagenomics analysis of gut microbiota and immune modulation in zebrafish (Danio rerio) fed chitosan silver nanocomposites. Fish Shellfish Immunol 2017; 66: 173-84.

[129] Nawaz A, Bakhsh Javaid A, Irshad S, Hoseinifar SH, Xiong H. The functionality of prebiotics as immunostimulant: Evidences from trials on terrestrial and aquatic animals. Fish Shellfish Immunol 2018; $76: 272-8$. 
[130] Reid G. Probiotics: definition, scope and mechanisms of action. Best Pract Res Clin Gastroenterol 2016; 30(1): 17-25.

[131] Chen J, Ren Y, Li Y, Xia B. Regulation of growth, intestinal microbiota, non-specific immune response and disease resistance of sea cucumber Apostichopus japonicus (Selenka) in biofloc systems. Fish Shellfish Immunol 2018; 77: 175-86.

[132] Zhang CN, Zhang JL, Guan WC, et al. Effects of Lactobacillus delbrueckii on immune response, disease resistance against Aeromonas hydrophila, antioxidant capability and growth performance of Cyprinus carpio Huanghe var. Fish Shellfish Immunol 2017; 68: 84-91.

[133] Zhang DX, Kang YH, Chen L, et al. Oral immunization with recombinant Lactobacillus casei expressing OmpAI confers protection against Aeromonas veronii challenge in common carp, Cyprinus carpio. Fish Shellfish Immunol 2018; 72: 552-63.

[134] Huynh TG, Shiu YL, Nguyen TP, Truong QP, Chen JC, Liu CH. Current applications, selection, and possible mechanisms of actions of synbiotics in improving the growth and health status in aquaculture: A review. Fish Shellfish Immunol 2017; 64: 367-82.

[135] Wang X, Sun Y, Wang L, Li X, Qu K, Xu Y. Synbiotic dietary supplement affects growth, immune responses and intestinal microbiota of Apostichopus japonicus. Fish Shellfish Immunol 2017; 68: 232-42.

[136] Vetvicka V, Vannucci L, Sima P. The Effects of $\beta$ - Glucan on Fish Immunity. N Am J Med Sci 2013; 5(10): 580-8.

[137] Gantner BN, Simmons RM, Canavera SJ, Akira S, Underhill DM. Collaborative induction of inflammatory responses by dectin-1 and Toll-like receptor 2. J Exp Med 2003; 197(9): 1107-17.

[138] Skiermo J, Storseth TR, Hansen K, Handa A, Oe G. Evaluation of Beta $(1 \rightarrow 3,1 \rightarrow 6)$ glucans and high-M alginate used as immunostimulatory dietary supplement during first feeding and weaning of atlantic cod (Gadus morhua L.). Aquaculture 2006; 261: 10881101.

[139] Reyes-Becerril, Guardiola FA, Sanchez V, Maldonado M, Angulo C. Sterigmatomyces halophilus $\beta$-glucan improves the immune response and bacterial resistance in Pacific red snapper (Lutjanus peru) peripheral blood leucocytes: In vitro study. Fish Shellfish Immunol 2018; 78: 392-403.

[140] Salah AS, El Nahas AF, Mahmoud S. Modulatory effect of different doses of $\beta-1,3 / 1,6$-glucan on the expression of antioxidant, inflammatory, stress and immune-related genes of Oreochromis niloticus challenged with Streptococcus iniae. Fish Shellfish Immunol 2017; 70: 204-13.

[141] Cárdenas-Reyna T, Angulo C, Guluarte C, Hori-Oshima S, ReyesBecerril M. In vitro immunostimulatory potential of fungal $\beta$ glucans in pacific red snapper (Lutjanus peru) cells. Dev Comp Immunol 2017; 77: 350-8.

[142] Layé S, Nadjar A, Joffre C, Bazinet RP. Anti-Inflammatory Effects of Omega-3 Fatty Acids in the Brain: Physiological Mechanisms and Relevance to Pharmacology. Pharmacol Rev 2018; 70(1): 1238

[143] Saini RK, Keum YS. Omega-3 and omega-6 polyunsaturated fatty acids: Dietary sources, metabolism, and significance - A review. Life Sci 2018; 203: 255-67.

[144] Cornet V, Ouaach A, Mandiki SNM, et al. Environmentallyrealistic concentration of cadmium combined with polyunsaturated fatty acids enriched diets modulated non-specific immunity in rainbow trout. Aquat Toxicol 2018; 196: 104-16.

[145] Wang T, Yang B, Ji R, Xu W, Mai K, Ai Q. Omega-3 polyunsaturated fatty acids alleviate hepatic steatosis-induced inflammation through Sirt1-mediated nuclear translocation of NF- $\mathrm{BB}$ p65 subunit in hepatocytes of large yellow croaker (Larmichthys crocea). Fish Shellfish Immunol 2017; 71: 76-82.

[146] Nayak S, Koven W, Meiri I, et al. Dietary arachidonic acid affects immune function and fatty acid composition in cultured rabbitfish Siganus rivulatus. Fish Shellfish Immunol 2017; 68: 46-53.

[147] Shi XC, Jin A, Sun J, et al. $\alpha$-lipoic acid ameliorates n-3 highlyunsaturated fatty acids induced lipid peroxidation via regulating antioxidant defenses in grass carp (Ctenopharyngodon idellus). Fish Shellfish Immunol 2017; 67: 359-67.

[148] Tian L, Zhou XQ, Jiang WD, et al. Sodium butyrate improved intestinal immune function associated with NF- $\mathrm{KB}$ and p38MAPK signalling pathways in young grass carp (Ctenopharyngodon idella). Fish Shellfish Immunol 2017; 66: 548-63.
[149] Leal E, Zarza C, Tafalla C. Effect of vitamin C on innate immune responses of rainbow trout (Oncorhynchus mykiss) leukocytes. Fish Shellfish Immunol 2017; 67: 179-88.

[150] Abo-Al-Ela, HG, El-Nahas AF, Mahmoud S, Ibrahim EM. Vitamin $\mathrm{C}$ Modulates the Immunotoxic Effect of $17 \alpha$-Methyltestosterone in Nile Tilapia. Biochem 2017; 56(14): 2042-50.

[151] Dawood MAO, Koshio S. Vitamin C supplementation to optimize growth, health and stress resistance in aquatic animals. Rev Aqualcult 2018; 10(2): 334-50

[152] Dioguardi M, Guardiola FA, Vazzana M, Cuesta A, Esteban MA, Cammarata $\mathrm{M}$. Vitamin $\mathrm{D}_{3}$ affects innate immune status of European sea bass (Dicentrarchus labrax L.). Fish Physiol Biochem 2017; 43(4): 1161-74.

[153] Jia Y, Jing Q, Niu H, Huang B. Ameliorative effect of vitamin E on hepatic oxidative stress and hypoimmunity induced by high-fat diet in turbot (Scophthalmus maximus). Fish Shellfish Immunol 2017; 67: $634-42$

[154] Ghafari Farsani H, Binde Doria H, Jamali H, Hasanpour S, Mehdipour N, Rashidiyan G. The protective role of vitamin E on Oreochromis niloticus exposed to ZnONP. Ecotoxicol Environ Saf 2017; 145: 1-7.

[155] Chen Y, Liu W, Wang X, et al. Effect of dietary lipid source and vitamin $\mathrm{E}$ on growth, non-specific immune response and resistance to Aeromonas hydrophila challenge of Chinese mitten crab Eriocheir sinensis. Aqualcult Res 2018; 49(5): 2023-32.

[156] Shahkar E, Hamidoghli A, Yun H, Kim D-J, Bai SC. Effects of dietary vitamin $\mathrm{E}$ on hematology, tissue $\alpha$-tocopherol concentration and non-specific immune responses of Japanese eel, Anguilla japonica. Aquacult 2078; 484(2018): 51-7.

[157] Magrone T, Russo MA, Jirillo E. Cocoa and Dark Chocolate Polyphenols: From Biology to Clinical Applications._Front Immunol 2017; 8: 677 .

[158] Magrone T, Jirillo E. Effects of Polyphenols on InflammatoryAllergic Conditions: Experimental and Clinical Evidences. In: Watson R, Preedy V. Polyphenols: Prevention and Treatment of Human Disease. Eds. Elsevier 2018, Second Edition, Vol. 2 pp. 253-59.

[159] Magrone T, Russo MA, Jirillo E. Antimicrobial Peptides: Phylogenic Sources and Biological Activities. First of Two Parts. Curr Pharm Des 2018; 24(10): 1043-53.

[160] Magrone T, Russo MA, Jirillo E. Antimicrobial Peptides in Human Disease: Therapeutic Approaches. Second of Two Parts._Curr Pharm Des 2018; 24(10): 1148-56.

[161] Marzulli G, Magrone T, Vonghia L, et al. Immunomodulating and anti-allergic effects of Negroamaro and Koshu Vitis vinifera fermented grape marc (FGM). Curr Pharm Des 2014; 20(6): 864-8

[162] Marzulli G, Magrone T, Kawaguchi K, Kumazawa Y, Jirillo E. Fermented grape marc (FGM): immunomodulating properties and its potential exploitation in the treatment of neurodegenerative diseases._Curr Pharm Des 2012; 18(1): 43-50.

[163] Kawaguchi K, Matsumoto T, Kumazawa Y. Effects of antioxidant polyphenols on TNF-alpha-related diseases. Curr Top Med Chem 2011; 11(14): 1767-79.

[164] Magrone T, Jirillo E, Spagnoletta A, et al. Immune Profile of Obese People and In Vitro Effects of Red Grape Polyphenols on Peripheral Blood Mononuclear Cells. Oxid Med Cell Longev 2017; 2017 : 9210862 .

[165] Magrone T, Jirillo E. Childhood obesity: immune response and nutritional approaches. Front Immunol 2015; 6: 76.

[166] Magrone T, Salvatore R, Spagnoletta A, Magrone M, Russo MA, Jirillo E. In Vitro Effects of Nickel on Healthy Non-Allergic Peripheral Blood Mononuclear Cells. The Role of Red Grape Polyphenols._Endocr Metab Immune Disord Drug Targets 2017; 17(2): $166-73$.

[167] Magrone T, Romita P, Verni P, et al. In vitro Effects of Polyphenols on the Peripheral Immune Responses in Nickel-sensitized Patients. Endocr Metab Immune Disord Drug Targets 2017; 17(4): 324-31.

[168] Magrone T, Spagnoletta A, Salvatore R, et al. Olive Leaf Extracts Act as Modulators of the Human Immune Response._Endocr Metab Immune Disord Drug Targets 2018; 18(1): 85-93.

[169] Alesci A, Cicero N, Salvo A, et al. Extracts deriving from olive mill waste water and their effects on the liver of the goldfish Carassius auratus fed with hypercholesterolemic diet. Nat Prod Res 2014; 28(17): 1343-9.

[170] Leiro J, Arranz JA, Paramá A, Alvarez MF, Sanmartín ML. In vitro effects of the polyphenols resveratrol, mangiferin and (-)- 
epigallocatechin-3-gallate on the scuticociliate fish pathogen Philasterides dicentrarchi. Dis Aquat Organ 2004; 59(2): 171-4.

[171] Zheng Y, Zhao Z, Wu W, et al. Effects of dietary resveratrol supplementation on hepatic and serum pro-/anti-inflammatory activity in juvenile GIFT tilapia, Oreochromis niloticus. Dev Comp Immunol 2017; 73: 220-8.

[172] Lutfi E, Babin PJ, Gutiérrez J, Capilla E, Navarro I. Caffeic acid and hydroxytyrosol have anti-obesogenic properties in zebrafish and rainbow trout models. PLoS One 2017; 12(6): e0178833.

[173] Magrone T, Fontana S, Laforgia F, Dragone T, Jirillo E, Passantino L. Administration of a Polyphenol-Enriched Feed to Farmed Sea Bass (Dicentrarchus labrax L.) Modulates Intestinal and Spleen Immune Responses._Oxid Med Cell Longev 2016; 2016: 2827567.

[174] Magrone T, Spagnoletta A, Magrone M, Russo MA, Corriero A, Jirillo E, Passantino L. Effects of polyphenol administration to European farmed sea bass (Dicentrharcus labrax L): Special focus on hepatopancreas morphology. Endocr Metab Immune Disord Drug Targets (in press).

[175] Munang'andu HM, Galindo-Villegas J, David L. Teleosts Genomics: Progress and Prospects in Disease Prevention and Control. Int J Mol Sci 2018; 19(4): pii: E1083.

[176] Huang PH, Chen JY, Kuo CM. Three different hepcidins from tilapia, Oreochromis mossambicus: analysis of their expressions and biological functions. Mol Immunol 2007; 44(8): 1922-34.

[177] Wang D, Li S, Zhao J, Liu H, Lu T, Yin J. Genomic organization, expression and antimicrobial activity of a hepcidin from taimen (Hucho taimen, Pallas). Fish Shellfish Immunol 2016; 56: 303-9.
[178] Guil L, Zhang P, Zhang Q, Zhang J. Two hepcidins from spotted scat (Scatophagus argus) possess antibacterial and antiviral functions. Fish Shellfish Immunol 2016; 50: 191-6.

[179] Chen J, Nie L, Chen J. Mudskipper (Boleophthalmus pectinirostris) hepcidin-1 and hepcidin-2 present different gene expression profile and antibacterial activity and possess distinct protective effect against Edwardsiella tarda infection. Probiotics Antimicrob Proteins $2017 ; 1-10$

[180] Alvarez CA, Guzmán F, Cárdenas C, Marshall SH, Mercado L. Antimicrobial activity of trout hepcidin. Fish Shellfish Immunol 2014; 41(1): 93-101.

[181] Ooi EL, Verjan N, Haraguchi I, et al. Innate immunomodulation with recombinant interferon-alpha enhances resistance of rainbow trout (Oncorhynchus mykiss) to infectious hematopoietic necrosis virus. Dev Comp Immunol 2008; 32(10): 1211-20.

[182] Kuo HP, Goh LL, Lu MW, Kong ZL. Delivery of grouper interferon by chitosan-modified poly (lactic-co-glucolic acid) nanoparticles to protect nervous necrosis virus infection. J Nanosci Nanotechnol 2016; 16: 7521-9.

[183] Gadan K, Sandtrø A, Marjara IS, Santi N, Munang'andu HM, Evensen Ø. Stress-induced reversion to virulence of infectious pancreatic necrosis virus in naïve fry of Atlantic salmon (Salmo salar L.) PLoS One 2013; 8(2): e54656.

[184] Xu C, Evensen Ø, Munang'andu HM. De Novo Transcriptome Analysis Shows That SAV-3 Infection Upregulates Pattern Recognition Receptors of the Endosomal Toll-Like and RIG-I-Like Receptor Signaling Pathways in Macrophage/Dendritic Like TO-Cells. Viruses 2016; 8(4): 114. 